\title{
Water Quality Assessment Based on Fish and Macroinverbrate Diversity Indices of River Mara Bharali in Assam, India
}

\author{
Das A.*1 and Biswas S.P2 \\ ${ }^{1}$ Department of Zoology, Darrang College, Tezpur, Assam, India \\ ${ }^{2}$ Department of Life Sciences, Dibrugarh University, Dibrugarh, Assam, India
}

\begin{abstract}
Fish and macroinvertebrate diversity was studied in the river Mara Bharali at Tezpur in the Sonitpur district of Assam as no such enumerative works on the river system was done previously. Five sampling stations (MB1, MB2, MB3, MB4 and MB5) covering a stretch of 16.5 kms were selected from Pumpani village (sampling station MB5, N-26 45'10.52" and E$\left.92^{\circ} 50^{\prime} 07.93^{\prime \prime}\right)$ to Maithan (sampling station MB1, N-26 $37^{\prime} 05.69^{\prime \prime}$ and E-92 $\left.{ }^{\circ} 49^{\prime} 34.34^{\prime \prime}\right)$. Fishes and invertebrates were collected and identified following relevant literatures. Thirty four (34) species of fishes of 25 genera, 08 orders and 17 families has been recorded. Cyprinids were found to be the most dominant group with 12 representative species. Twenty (20) species of aquatic insects belonging to 13 families and 7 orders were found. Moreover, six (06) molluscan species belonging to 5 different families were also recorded. Shannon diversity index $(\mathrm{H})$ for macroinvertebrates was highest in sector MB1 (4.468). Pielou equitability index (J) was highest at MB4 (0.9805). The value of Margalef index (Ma) was highest at MB4 (3.831) and lowest at MB3 (1.861). Sector-wise diversity indices of macroinvertebrates reflect the ecological status of river Mara Bharali. The macroinvertebrates of all the sites are evenly distributed as the calculated value of $\mathrm{J}$ is close to 1 . On the basis of the value of macroinvertebrate diversity index, it may be concluded that river Mara Bharali is quiet healthy at sectors MB1, MB4 and MB5 as the Margalef index is greater than 3. However, sectors MB2 and MB3 are likely to be polluted as the value of Ma is less than 3.
\end{abstract}

Keywords: R.Mara Bharali, macroinvertebrate, diversity index, Cyprinids, aquatic insects, habitat quality

\section{Introduction}

Rivers always borrow a great part of their character from the terrestrial ecosystem that is the catchment through which they flow. Indeed, if the landscape is in a good condition, then the river is too, and if the landscape is badly treated, then the river flowing through it will magnify and mirror that abuse (Davies and Day, 1998). Rapid industrialization, water abstraction and the extensive use of pesticides in agriculture have severe strains on rivers and resulted in deterioration of water quality. Freshwater habitats harbour diverse fauna, with fish serving as prime indicators of ecosystem status (Karr et al. 1986). Riverine fauna show a high degree of endemism, with most endemic fish species living in headwater streams and/or short stretches of river (Groombridge 1992; Kottelat \& Whitten 1997).

The river Jia Bharali is one of the largest tributaries of the Brahmaputra in the north bank. It is known as Kameng river in neighbouring Arunachal Pradesh. Originating from the Indo- China border, it traverses about $242 \mathrm{~km}$ before meeting the Brahmaputra near Bhomoraguri, Tezpur. The old channel of Jia Bharali named as Mara Bharali shows meandering pattern. Sometimes prior to 1824 the major change in the shift of the river course from the Mara Bharali to the present one has taken place. It is very important to assess the quality of river water. People along the river use water for many purposes. However, the surface water quality deteriorates due to anthropogenic activities, industrialization, farming activities, transportation, urbanization, animal and human excretions and domestic wastes. Aquatic organisms need a healthy environment. Maximum productivity depends on optimum level of physicochemical parameters (Sadia et al., 2013). 
Molluscs are a group of most diverse and dominant benthic fauna in waterbodies, perform a key role in the functioning of aquatic ecosystem. Molluscans are of great significance because they form the food of fishes and their productivity play an important link in the food chain. Molluscan communities are good indicators of localised conditions, indicating the water quality. The freshwater ecosystems in India harbour a rich diversity of molluscs, representing 212 species belonging to 21 families. Of these, 164 species were recorded from rivers and streams (Subba Rao, 1993). The presence of thriving population of molluscan indicates that water is not acidic. The freshwater bivalves act as natural filtering in lakes and rivers as they consume large quantities of diatoms, blue-green algae, bacteria, organic particles, as well as silt and absorb heavy metals (Morton, 2012).

Moreover, fishing is considered as the main economic activity in the beels and rivers of Assam. The fishing habitats of Assam had degraded as a consequence of natural as well as ever increasing human interferences (Biswas and Boruah, 2002). Assam has an excellent subtropical climate for development of freshwater fish culture in variety of aquatic bodies. Assessment and classification of ecological water quality using indices based approaches can help the conservation and management of rivers. Physicochemical parameters can only show water quality at the moment of measurement and these can change over time. Nowadays, indicators based on the presence or absence of aquatic organisms has been developed to assess water quality and for the classification of ecological status. Effects on biota are usually the final point of environmental degradation and pollution of rivers and thus are an important indication of ecosystem health (Norris and Thoms, 2015). Therefore, the study has been conducted in Mara Bharali river in the Sonitpur district of Assam with the following two objectives:

- To assess the fish and macro-invertebrate diversity of Mara Bharali river

- Assessment of the water quality of the riverine system on the basis of evaluation of fish and macroinvertebrate diversity index

\section{Materials and Methods}

\section{About the study area}

Sampling stations were selected in the old channel of Jia Bharali named as Mara Bharali (at 05 sampling stations) from Pumpani village (N-26 45'10.52" and E-92 50'07.93") to Maithan (N-26 37'05.69" and E92 49'34.34"), Tezpur where it meets the river Brahmaputra. The 05 sampling stations has been demarcated as MB5 (Pumpani village, N-26 $45^{\prime} 10.52^{\prime \prime}$ and E-92 $\left.{ }^{\circ} 50^{\prime} 07.93^{\prime \prime}\right)$, MB4 (Amlopam village, N-26 $41^{\prime} 16.84^{\prime \prime}$ and E92 48'58.88"), MB3 (Dolabari village, N-26 40'00.65" and E-92 49'43.64"), MB2 (Porowa Bridge, N26 $39^{\prime} 10.05^{\prime \prime}$ and E-92 $47^{\prime} 49.28^{\prime \prime}$ ) and MB1 (Maithan, N-26 37'05.69" and E-92 49'34.34") that covers a stretch of about $16.5 \mathrm{~km}$. 


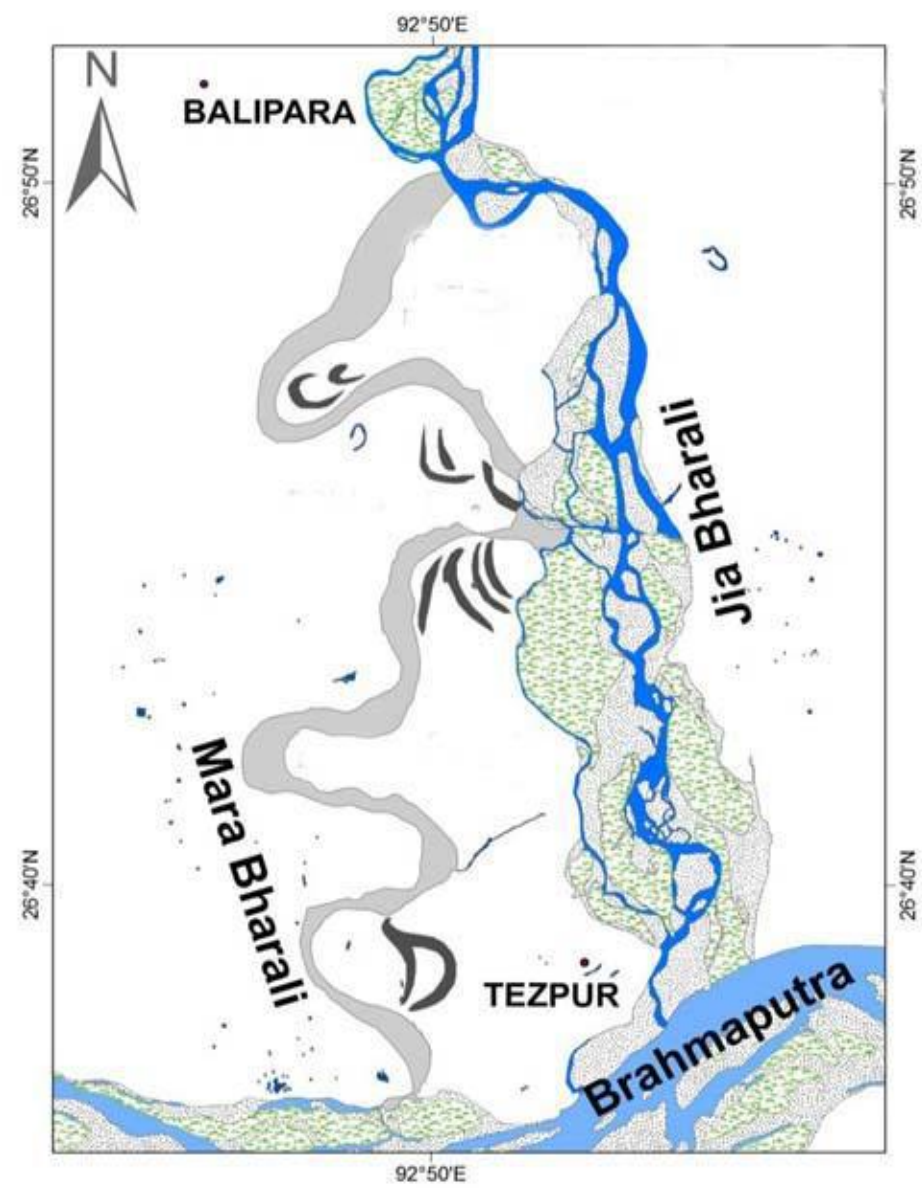

Fig 1: Map showing the study area, river Mara Bharali at Tezpur in the Sonitpur district of Assam

\section{Methodology}

Collection and identification of fishes and macroinvertebrates:

(a) Fish of the wetland: Fishes were collected and identified following Talwar \& Jhingran (1991).

(b) Macroinvertebrates from each sampling stations were collected using dragging net following the protocols of Barbour et al. (1999) and Mandaville (2002). Collected species were washed, photographed with the help of a digital camera and identified as per Pennak (1989), Subba Rao (1989), Edmondson (1993) and Merrit and Cummins (1996).

\section{Sampling}

The molluscs of the littoral zone were collected by hand picking and the small species were separated using a sieve. The samples were brought to the laboratory, washed and then preserved in 70 percent alcohol. Live mussels were stored at a low temperature and were placed in the coldest part of refrigerator.

(c) Diversity indices were calculated as per standard protocols described below. 


\section{Shannon's diversity index $(\mathrm{H})$}

This index accounts for both evenness and abundance of the species present at any given time $\mathrm{H}=\sum\left(\frac{\mathrm{n}_{\mathrm{i}}}{\mathrm{N}}\right) \log _{2}\left(\frac{\mathrm{n}_{\mathrm{i}}}{\mathrm{N}}\right)$

where, ni= No. of individuals belonging to ith species; $\mathrm{N}=$ Total no. of individuals in the sample

\section{Simpson's dominance (D) and diversity index (1-D)}

It is designed to measure the probability of any two randomly selected individuals from an infinitely large community belonging to the same species

$$
\begin{aligned}
& \text { Simpson's dominance (D) }=\frac{\sum \mathrm{n}_{\mathrm{i}}\left(\mathrm{n}_{\mathrm{i}}-1\right)}{\mathrm{N}(\mathrm{N}-1)} \\
& \text { Simpson's diversity }(1-\mathrm{D})=1-\left[\frac{\sum \mathrm{n}_{\mathrm{i}}\left(\mathrm{n}_{\mathrm{i}}-1\right)}{\mathrm{N}(\mathrm{N}-1)}\right]
\end{aligned}
$$

where, ni= Total no. of individuals belonging to ith species; $\mathrm{N}=$ Total no. of organisms of all species

\section{Margalef's diversity index (Ma)}

It is also represent a species richness index which measure the number of different species in a given area

$\mathrm{Ma}=\frac{\mathrm{S}-1}{\ln \mathrm{N}}$

where, $\mathrm{N}=$ Total no. of individuals in the sample; $\mathrm{S}=$ Total no. of species

\section{Pielou's evenness index (J)}

It measures the equitable distribution of individuals in the community, the value of which range between 0 and 1.

$$
\mathrm{I}=\frac{\mathrm{H}}{\mathrm{H}_{\max }}
$$

where, $\mathrm{H}=$ Value of Shannon index; Hmax $=\ln \mathrm{S} ; \mathrm{S}=$ Total no. of species

\section{Results}

In the present investigation fish and macroinvertebrate diversity of river Mara Bharali has been studied and the aquatic health or habitat quality of the river system has been analyzed on the basis of calculated diversity indices.

\section{Fish diversity of Mara Bharali river}

The collected fish species from the five sampling stations including their order, family, scientific name and common name are depicted in Table-2. A total of 34 species belong 25 genera, 08 orders and 17 families has 
been identified so far during the period of investigation (Table 4). The fish fauna of the river belongs to the order Cypriniformes, Siluriformes, Synbranchiformes, Perciformes, Tetradontiformes, Anguilliformes, Clupeiformes and Beloniformes. Cyprinids were the most dominant group represented by 12 species with total species contribution of $35.3 \%$ followed by Perciformes 09 species (26.47\%), Siluriformes 06 species (17.65\%) and Beloniformes 03 species $(8.82 \%)$. The rest of the orders that is, Synbranchiformes, Tetradontiformes, Anguilliformes and Clupeiformes were represented by 01 species each with a species share of 2.94\% (Fig. 2).

\section{Distribution and abundance of macro-invertebrates}

The study revealed the presence of 20 species of aquatic insects belonging to 13 families and 7 orders at five different sampling sites of river Mara Bharali (Table 1 \& Fig. 3). The orders are Ephemeroptera, Hemiptera, Trichoptera, Coleoptera, Decapoda, Diptera and Odonata. Insect species were dominated by the orders Hemiptera and Decapoda with 4 and 5 representatives of each respectively. The representative species of Hemiptera are Laccotrephes sp., Curicta sp., Micronecta sp. and Notonecta sp. The representative species of Decapoda include Macrobrachium carcinus, Macrobrachium malcolmsonii, Macrobrachium choprai, Macrobrachium assamense and Macrobrachium birmanicum. Moreover, 6 molluscan species has also been recorded from the area of study. The molluscan species belonged to 5 different families and they are Viviparidae, Planorbidae, Pachychilidae, Ampullariidae and Bithyniidae. Molluscs were dominated by Gastropods with 5 representatives (Bellamya bengalensis, Gyrulus convexiusculus, Brotia costula, Pila globosa and Gabbia sp.). Only, 1 representative of Bivalvia was identified from the area of study (Lamellidens sp.). The Site-1, 4 and 5 were found to be rich in macro-invertebrate species diversity and Site-1(MB1) was found to harbour all the 6 molluscan species collected and identified from the riverine system. Among the insects, Laccotrephes sp., Notonecta sp., Hydaticus sp. and Hydrophilus sp. were the most dominant species. Gyrulus convexiusculus, Brotia costula and Pila globosa were the dominant molluscan species in the aquatic system (Table 1 \& Fig. 3).

Table 1: Distribution of macro-invertebrate fauna of Mara Bharali river

\begin{tabular}{|c|c|c|c|c|c|}
\hline S1. No. & Macro-invertebrate species & Family & Order & Site & Abundance \\
\hline 1 & Isonychia sp. & Isonychidae & Ephemeroptera & $\mathrm{MB}(1,4,5)$ & + \\
\hline 3 & Diplonychus sp. & Belostomatidae & Ephemeroptera & $\operatorname{MB}(1,2,3,4,5)$ & ++ \\
\hline 4 & Laccotrephes sp. & Nepidae & Hemiptera & $\operatorname{MB}(1,2,3,4,5)$ & +++ \\
\hline 6 & Micronecta sp. & Notonectidae & Hemiptera & $\operatorname{MB}(1,4,5)$ & + \\
\hline 7 & Notonecta sp. & Notonectidae & Hemiptera & $\operatorname{MB}(1,3,4,5)$ & +++ \\
\hline 8 & Stenopsyche sp. & Stenopsychidae & Trichoptera & $\operatorname{MB}(1,4,5)$ & + \\
\hline 9 & Hydaticus sp. & Dytiscidae & Coleoptera & $\operatorname{MB}(2,4,5)$ & +++ \\
\hline 13 & Macrobrachium assamense & Palaemonidae & Decapoda & $\operatorname{MB}(4,5)$ & ++ \\
\hline 14 & Macrobrachium birmanicum & Palaemonidae & Decapoda & $\operatorname{MB}(1,2,3,4)$, & + \\
\hline 15 & Chironomus sp. & Chironomidae & Diptera & $\mathrm{MB}(1,2,3,4,5)$ & + \\
\hline 16 & Culex sp. & Culicidae & Diptera & $\mathrm{MB}(1,2,3,4,5)$ & + \\
\hline 17 & Lestes sp. & Lestidae & Odonata & $\mathrm{MB}(1,3,4)$ & ++ \\
\hline
\end{tabular}


Das A. and Biswas S.P/ Water Quality Assessment Based on Fish and Macroinverbrate Diversity.....

\begin{tabular}{|l|l|l|l|l|l|}
\hline 18 & Hydrophilus $s p$. & Hydrophilidae & Coleoptera & $\mathrm{MB} 1$ & +++ \\
\hline 19 & Laccophilus $s p$. & Dytiscidae & Coleoptera & $\mathrm{MB}(1,2,3)$ & + \\
\hline 20 & Dragon fly ( nymph $)$ & Aeshnidae & Odonata & $\mathrm{MB}(1,4,5)$ & ++ \\
\hline 21 & Bellamya bengalensis & Viviparidae & --- & $\mathrm{MB}(1,4)$ & ++ \\
\hline 22 & Gyrulus convexiusculus & Planorbidae & --- & $\mathrm{MB}(1,5)$ & +++ \\
\hline 23 & Brotia costula & Pachychilidae & --- & $\mathrm{MB}(1,4)$ & +++ \\
\hline 24 & Pila globosa & Ampullariidae & --- & $\mathrm{MB}(1,2,3,4,5)$ & +++ \\
\hline 25 & Lamellidens $s p$. & Ampullariidae & Unionoida & $\mathrm{MB}(1,4)$ & + \\
\hline 26 & Gabbia $s p$. & Bithyniidae & Littorinimorpha & $\mathrm{MB}(1,4,5)$ & ++ \\
\hline
\end{tabular}

Table 2: Fish species recorded in Mara Bharali

\begin{tabular}{|c|c|c|c|c|}
\hline Sl. No. & Order & Family & Scientific name & Local name \\
\hline 1 & Cypriniformes & Cyprinidae & Labeo rohita & Rohu \\
\hline 2 & & & Labeo gonius & Kuri \\
\hline 3 & & & Labeo calbasu & Mali \\
\hline 4 & & & Cirrhinus mrigala & Mirika \\
\hline 5 & & & Aspidoparia morar & Boliora \\
\hline 6 & & & Chela atpar & Selkona \\
\hline 7 & & & Amblypharyngodon mola & Moa \\
\hline 8 & & & Puntius sophore & Puthi \\
\hline 9 & & & Puntius sarana & Cheni puthi \\
\hline 10 & & & Esomus denricus & Darikona \\
\hline 11 & & & Resbora elenga & Eleng \\
\hline 12 & & Cobitidae & Lepidocephalus guntea & Botia \\
\hline 13 & Siluriformes & Bagridae & Mystus bleekeri & Singorah \\
\hline 14 & & & Mystus cavasius & Borsingora \\
\hline 15 & & & Mystus vittatus & Tingora \\
\hline 16 & & Siluridae & Wallago attu & Barali \\
\hline 17 & & Claridae & Clarias batrachus & Magur \\
\hline 18 & & Heteropneustidae & Heteropneustes fossilis & Singi \\
\hline 19 & Synbranchiformes & Synbranchidae & Monopterus cuchia & Cuchia \\
\hline 20 & Perciformes & Nandidae & Nandus nandus & Gadgedi \\
\hline 21 & & Centropomidae & Chanda nama & Chanda \\
\hline 22 & & Anabantidae & Anabus testudenius & Kawai \\
\hline 23 & & & Colisa fasciatus & Kholihona \\
\hline 24 & & Channidae & Channa gachua & Cheng \\
\hline 25 & & & Channa marulius & Sal \\
\hline 26 & & & Channa punctatus & Goroi \\
\hline 27 & & & Channa striatus & Sol \\
\hline 28 & & Gobiidae & Glossogobius giuris & Patimutara \\
\hline 29 & Tetradontiformes & Tetradontidae & Tetradon cutcutia & Gangatop \\
\hline 30 & Anguilliformes & Anguillidae & Anguilla bengalensis & Bami \\
\hline 31 & Clupeifomes & Notopteridae & Notopterus notopterus & Kanduli \\
\hline
\end{tabular}




\begin{tabular}{|l|l|l|l|l|}
\hline 32 & Beloniformes & Belonidae & Xenentodon cancila & Kokila \\
\hline 33 & & Mastacembalidae & Macrognathus pancalus & Tora \\
\hline 34 & & & Macrognathus aral & Tora bami \\
\hline
\end{tabular}

Table 3: Calculated value of diversity indices in the area of study

\begin{tabular}{|l|l|l|l|l|l|}
\hline Sites & $\begin{array}{l}\text { Shannon Index } \\
(\mathrm{H})\end{array}$ & $\begin{array}{l}\text { Simpson Index } \\
(\mathrm{D})\end{array}$ & $\begin{array}{l}\text { Simpson } \\
\text { diversity Index } \\
(1-\mathrm{D})\end{array}$ & Pielou Index (J) & $\begin{array}{l}\text { Margalef } \\
\text { richness index } \\
(\text { Ma })\end{array}$ \\
\hline MB1 & 4.468 & 0.0465 & 0.9535 & 0.9745 & 3.784 \\
\hline MB2 & 3.273 & 0.1089 & 0.8911 & 0.9462 & 2.03 \\
\hline MB3 & 3.214 & 0.1086 & 0.8914 & 0.9674 & 1.861 \\
\hline MB4 & 4.436 & 0.0457 & 0.9542 & 0.9805 & 3.831 \\
\hline MB5 & 4.064 & 0.0625 & 0.9375 & 0.9567 & 3.156 \\
\hline
\end{tabular}

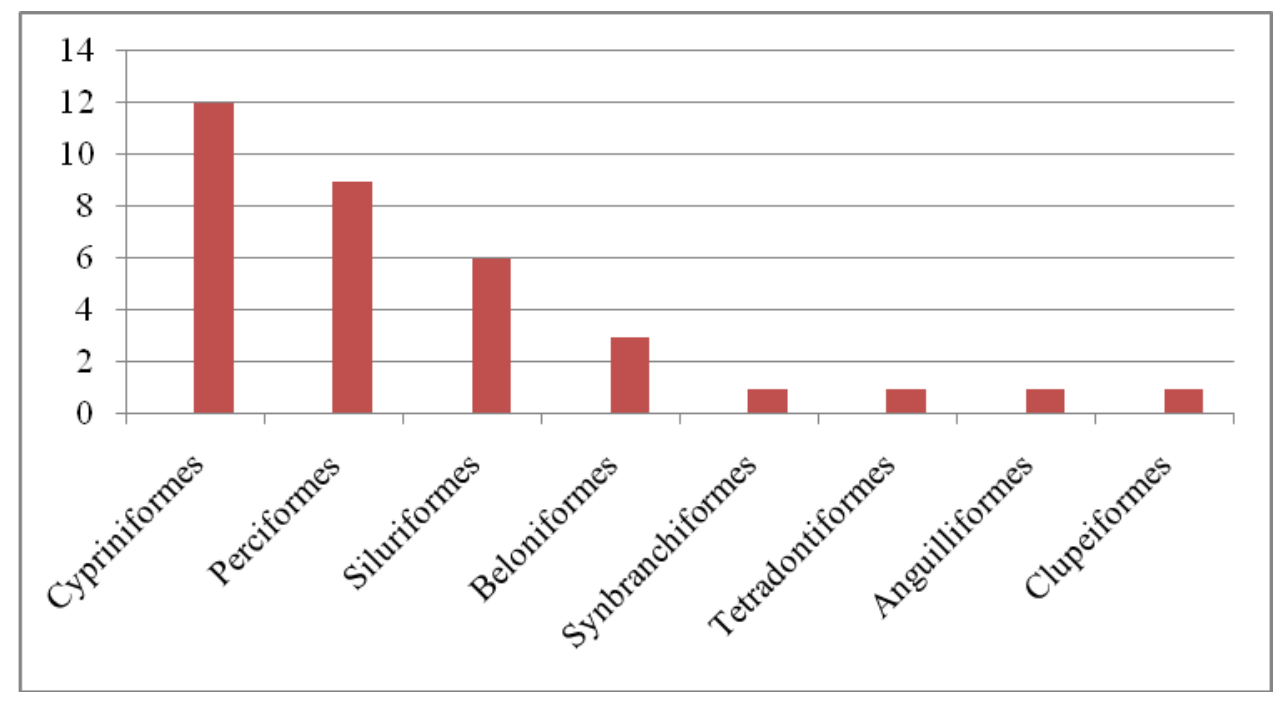

Figure 2: Graph showing the abundance of different species of fish belonging eight different orders in R.Mara Bharali

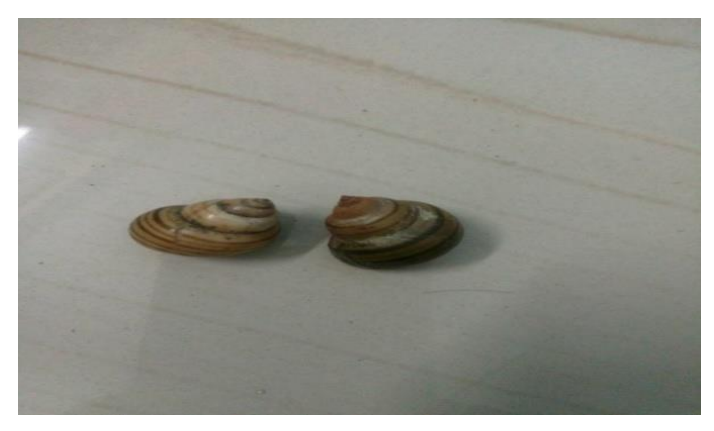

Gyraulus convexiusculus

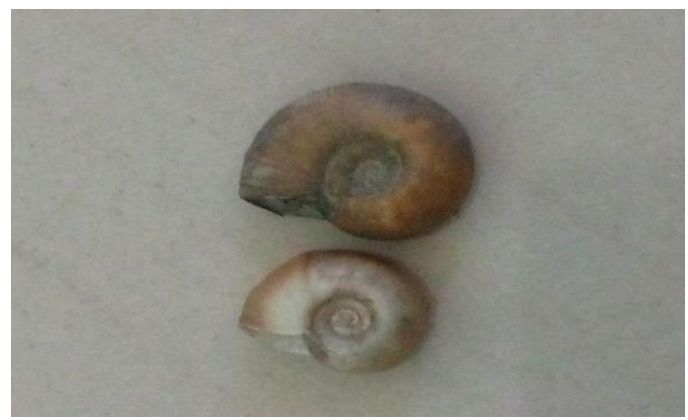

Gabbia orcula 


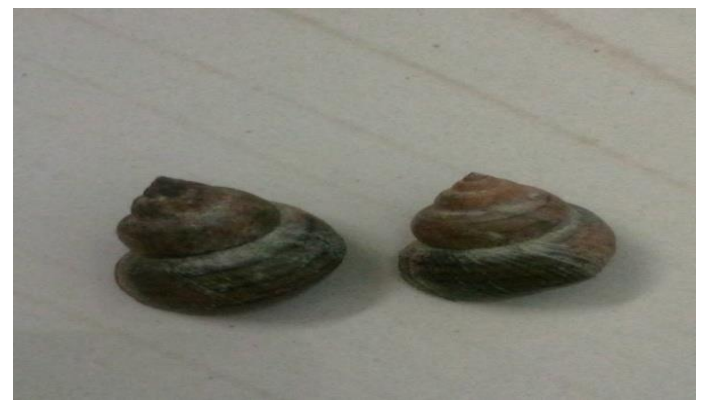

Bellamya bengalensis

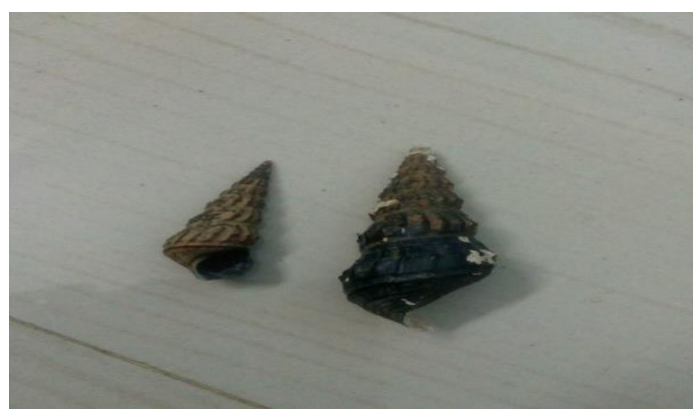

Brotia costula

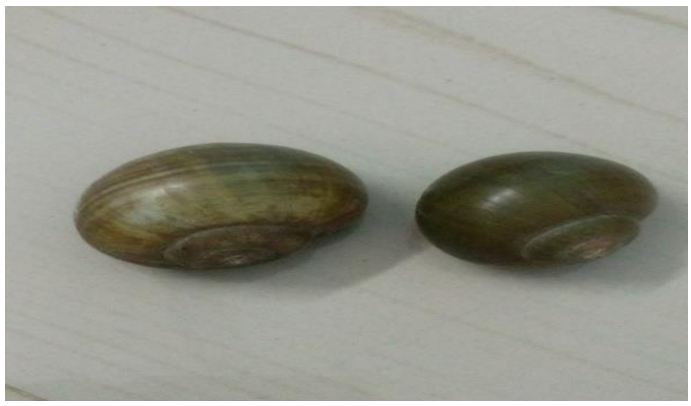

Pila globosa

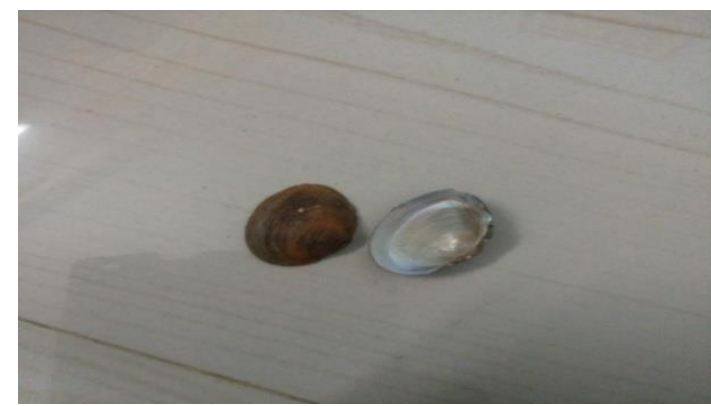

Lamellidens marginalis

Figure 3: Molluscan species collected and identified from river Mara Bharali

\section{Discussion of Findings}

In the present investigation 06 (six) molluscan species belonging to two classes, six families and six genera has been identified so far. A similar study was conducted on the molluscan community of Bharathapuzha river in Kerala and thirteen species of molluscs belonging to five orders, eight families and ten genera were reported (Bijukumar et al., 2001). Suryawansi et al. (2012) studied biodiversity of molluscs from river Godavari, reservoir and pond and reported 24 species of freshwater molluscs. A similar study in Kunda river of Madhya Pradesh, India found 43 species of macroinvertebrates belonging to phylum Annelida, Arthropoda and Mollusca. Their abundance and fluctuation was found to depend upon environmental conditions and physicochemical parameters of water (Sharma et al., 2016). The abundance of the molluscan fauna indicates rich productivity. The species inhabiting bottom of the river play an important role in converting organic matter into biomass which in turn is consumed by fishes. Thus the molluscs help in secondary productivity and form an important component in the food web of the river ecosystem. The molluscan diversity of R. Mara Bharali indicates that productivity of the aquatic system is moderately rich.

The river Mara Bharali also hosts a large number of freshwater fish species and 34 freshwater fishes has been identified so far. The fish species of the river is also under threat due to several anthropogenic factors including habitat degradation, pollution and irrational fishing. Since the fish fauna in this aquatic system supports the livelihood of several economic classes there is an urgent need to understand the conservation priorities and design and implement conservation action plans.

Moreover, Shannon diversity index of macroinvertebrates was highest in sector MB1 (4.468) and lowest in sector MB3 (3.214). Simpson's index of dominance (D) was highest in sector MB2 (0.1089) and lowest in sector MB4 (0.0457). However, Simpson's index of diversity was highest in sector MB4 (0.9542). Pielou equitability index (J) was highest at MB4 (0.9805) followed by MB1 (0.9745), MB3 (0.9674), MB5 (0.9567) and lowest at MB2 (0.9462). The value of Margalef index was highest at MB4 (3.831), followed by MB1 (3.784), MB5 (3.156), MB2 (2.03) and lowest at MB3 (1.861). Sector-wise diversity indices of macroinvertebrates reflect the ecological status of river Mara Bharali. The macroinvertebrates of all the sites are 
evenly distributed as the calculated value of $\mathrm{J}$ is close to 1 . Margalef's index value shows the similar trend with that of Shannon index. On the basis of the value of macroinvertebrate diversity index, it may be considered that R. Mara Bharali is quiet healthy at sectors MB1, MB4 and MB5 as the Margalef index value is greater than 3. It indicates substantially clean aquatic conditions at sectors MB1, MB4 and MB5 whereas sectors MB2 and MB3 is likely to be polluted as the value of Ma is less than 3 (Table 3). In a similar study on river Indus, 10 species of freshwater bivalves were collected and Shannon Weiner diversity index showed all selected sites of Indus having significant species diversity of bivalve belonging to family Unionidae (Shafiullah et al., 2017). Thus diversity indices and bio monitoring is a good tool for the quality assessment of water body.

\section{Conclusion}

The study shows that river Mara Bharali is a good resource of diverse freshwater fauna and also helped studying aquatic vertebrates and invertebrates with their diversity indices. Therefore, further studies may be conducted for the exploration of this group of economically and ecologically important fauna. The abundance of the molluscan fauna indicates the rich productivity of the ecosystem. The species inhabiting bottom of the river play an important role in converting organic matter together with the meiobenthos into biomass which in turn is consumed by the fishes. Thus the molluscs help in the secondary productivity and form an important component in the food web of the river ecosystem. Biomonitoring is a good tool for the assessment of water body as it needs no chemical means, ecofriendly, cost effective and moderately accurate. Future studies may therefore be conducted on fishing gears used is the area of study and Family biotic index may be utilized as an additional tool for assessment of water quality. Moreover, physico-chemical studies will also be taken up in future research to compare the ecological parameters.

\section{Recommendation}

1. A continuous monitoring of the physico-chemical and biological parameters of this river is needed for in-situ conservation of aquatic biodiversity.

2. Assessment of human intervention and various anthropogenic factors also needs to be addressed for the conservation of the ecosystem.

\section{References}

Barbour MT, Gerritsen J and Snyder BD (1999). Stribling rapid Bioassessment protocols for use in streams and wadeable rivers: Periphyton benthic macroinvertebrates and fish (2nd Edition). U.S. Environmental Protection Agency, Washington D.C., 106pp.

Bijukumar A, Sushama S and Biswas T (2001). Molluses collected from the Bharathpuzha River, Kerala. Journal of the Inland Fisheries Society of India, 33(2), $68-69$.

Biswas SP and Boruah S (2002). Ecology and fisheries of the Brahmaputra River. Bulletin of Life Sciences, 10, 91-106.

Davies B and Day J (1998). Vanishing waters. University of Cape Town press, Cape Town, South Africa, 487pp.

Edmondson WT (1993). Ward and Whipple's Fresh Water Biology (2nd Edition). John Wiley and Sons, New York.

Groombridge B (1992). Global biodiversity status of earth's living resources. Chapman and Hall, London, $585 \mathrm{pp}$.

Joshi BD and Bisht RC (1993). Some aspects of physic-chemical characteristics of Western Ganga canal near Jwalapur at Haridwar. Himalayan Journal of Environmental Zoology, 7, 76 - 82.

Karr JR, Fausch KD, Angermeier PL, Yant PR and Schlosser IJ (1986). Assessing biological integrity in running waters: a method and its rationale III. Natural History Survey, 5, 28. 
Kottelat M and Whitten T (1997). Freshwater biodiversity in Asia with special reference to fishes. The world bank Technical Report No. 343, Washington DC, 59pp.

Mandaville SM (2002). Benthic macroinvertebrates in freshwater - Taxa Tolerance Values, Metrics and Protocols. Project H - 1, Soil and Water Conservation Society of Metro Halifax. xviii, 48p, Appendices A - B, 120pp.

Merritt RW and Cummins KW (1996). An introduction to Aquatic insects of North America (3rd Edition). Kendall-Hunt, ISBN- 0-7872-3241-6, 862pp.

Morton B (2012). Bivalve: The mantle and musculature”. Encyclopaedia Britannica.

Norris RH and Thoms MC (2015). What is river health? Freshwater Biology, 41(2), 197-209.

Parashar NB, Kaushik P and Pandey S (2003). Physico-chemical and Microbiological Studies of Ganga Canal at Haridwar during Kumbh period, 1998. Himalayan Journal of Environmental Zoology, 17(2), 167 - 171.

Pennak RW (1989). Fresh invertebrates of the United States; Protozoa to Mollusca. John Wiley and Sons, New York.

Sadia A, Feroza HW, Imran Q, Muhammad Hamid SW, Tirmizi SA and Muhammad AQ (2013). Monitoring of anthropogenic influences on underground and surface water quality of Indus River at district Mianwali-Pakistan. Turk.ish Journal of Biochemistry, 38(1), 25-30.

Sawyer CN, McCarty PL and Parkin GF (2003). Chemistry for Environmental Engineering and Science, 5th edition, McGraw-Hill, New York.

Shafiullah M, Qureshi NA, Altaf J and Jabeen F (2017). Assessment of diversity and distribution of Bivalves (Mollusca: Bivalvia) in the Indus river district Mianwali, Pakistan. Journal of Biodiversity and Environmental Sciences, 10(6), 321-329.

Sharma S, Dubey S and Chaurasia R (2016). Aquatic benthic macro-invertebrate diversity of Kunda river district Khargone (M.P) India. Global Journal of Biology, Agriculture and Health Sciences, 2(4), 203-204.

Subba Rao NV (1989). Hand Book- Freshwater Molluscs of India. Published by Zoological Survey of India, Calcutta, 165pp.

Subba Rao NV (1993). In K.S. (ed.), Recent Advance in Freshwater Biology, Vol. II, Anmol Publication, New Delhi, India, 187-201.

Suryawanshi AV, Bhowate Cs and Kulkarni AN (2012). Freshwater Molluscs from Nanded, Maharashtra, India. Bioinfolet, 9(4B), $732-733$.

Talwar PK and Jhingran AG (1991). Inland Fisheries of India and Adjacent Countries (Vol. 1 \& 2). Oxford IBH Publication, New Delhi, 1158pp.

Thilaga A, Subhashini S, Logan K and Shobana S (2004). Studies on the variation in the physico-chemical parameters of a lake at Ooty (The Nilgiris). Himalayan Journal of Environmental Zoology, 18(1), $81-84$. 